\title{
ANALISIS PENGELOLAAN DAN AKUNTABILITAS LAPORAN KEUANGAN BADAN USAHA MILIK DESA (BUMDes) DI KECAMATAN GUNUNGSARI KABUPATEN LOMBOK BARAT
}

\author{
Ni Nyoman Ira Indriyanthi \\ iraindriyanthii@gmail.com \\ Jurusan Akuntansi Fakultas Ekonomi dan Bisnis Universitas Mataram \\ Nurabiah \\ nurabiah@unram.ac.id \\ Jurusan Akuntansi Fakultas Ekonomi dan Bisnis Universitas Mataram \\ Wirawan Suhaedi \\ wirawan.suhaedi@unram.ac.id \\ Jurusan Akuntansi Fakultas Ekonomi dan Bisnis Universitas Mataram
}

\begin{abstract}
ABSTRAK
Penelitian ini bertujuan untuk mengetahui pengelolaan dan akuntabilitas laporan keuangan dari Badan Usaha Milik Desa (BUMDes) yang berada di Kecamatan Gunungsari Kabupaten Lombok Barat. Metode penelitian yang digunakan deskriptif pendekatan kualitatif dengan teknik pengumpulan data melalui wawancara dan purposive sampling. Adapun informan pada penelitian ini yaitu Ketua BUMDes, Kepala Desa yang secara ex officio selaku Penasihat BUMDes dan Ketua BPD selaku Pengawas dari BUMDes.

Hasil penelitian ini dapat disimpulkan bahwa untuk pengelolaan maupun akuntabilitas dari laporan keuangan BUMDes belum berjalan dengan baik. Berdasarkan hasil wawancara berdasarkan indikator pengelolaan, kepengurusan BUMDes saat ini baru terbentuk sehingga belum berjalan maksimal. Karena hal tersebut pula dari pihak BUMDes juga belum membuat dan menyerahkan pertanggungjawaban dalam bentuk laporan keuangan kepada Kepala Desa dan Ketua BPD, sehingga dapat dikatakan bahwa BUMDes belum maksimal dan harus bekerja lebih keras untuk dapat maju, berkembang dan memberikan sumbangsih kepada desa masing-masing. Selain informasi yang kurang, hasil dokumentasi juga tidak sepenuhnya lengkap seperti yang diharapkan karena keterbatasan jangkauan penelitian akibat dari Covid-19. Kebaharuan penelitian ini adalah dimana peneliti menganalisis mengenai pengelolaan yang meliputi perkiraan (forecasting), perencanaan (planning), pengorganisasian (organizing), pelaksanaan (actuating) dan pengendalian (controlling). Sementara untuk akuntabililtas meliputi akuntabilitas vertikal (internal) dan akuntabilitas horizontal (ekstsernal). Secara teoritis, penelitian ini dapat memberikan implikasi yang luas mengenai stewardship theory. Secara praktis, penelitian ini memberikan implikasi bagi pihak pengurus BUMDes agar lebih baik dan disiplin mengenai pengelolaan BUMDes dan pelaporan keuangan BUMDes agar mempermudah apabila diminta mengenai pengecekan laporan keuangan dalam bekerja. Secara kebijakan, penelitian ini memberikan implikasi bagi pihak pengurus BUMDes agar kedepannya lebih memperdalam pengetahuan atau teori mengenai BUMDes sehingga dalam menjalankan pengelolaan BUMDes akan lebih maksimal terutama mengenai pelaporan keuangan BUMDes.
\end{abstract}

Kata kunci: Pengelolaan, Akuntabilitas, Laporan Keuangan, BUMDes.

\begin{abstract}
This research aims to determine the management and accountability of financial statements from village owned enterprises (BUMDes) located in Gunungsari district of West Lombok Regency. The research methods used are descriptive qualitative approaches with data collection techniques through interviews and purposive sampling. As for the informant on this research is the chairman of BUMDes, the head of the village who is ex officio as advisor BUMDes and chairman of BPD as supervisor of BUMDes. The results of this research can be concluded that for the management and accountability of the financial statements BUMDes has not been going well. Where from interviews based on management indicators, BUMDes Management is now newly formed so that it hasn't walked the maximum. Because of this, BUMDes also has not made and handed the accountability in the form of financial statements to the head of village and chairman of the BPD, so it can be said that BUMDes is not maximal and should work harder to be able to progress, develop and contribute to the village respectively. In addition to lacking information,
\end{abstract}


documentation results are also not entirely complete as expected due to limited research coverage due to Covid19. Newness this research is where researchers analyze the management which includes forecasting, planning, organizing, actuating and controlling. While for accountability includes vertical accountability (internal) and horizontal accountability (external). Theoretically, this research can provide broad implications regarding stewardship theory. Practically, this research provides the implications for BUMDes administrators to better and discipline the management of BUMDes and BUMDes Financial reporting to make it easier when asked to check the financial statements in the works. By policy, this research provides implications for BUMDes administrators so that the future is more deepening knowledge or theory about BUMDes so in order to run the management of BUMDes will be maximal especially regarding $B U M D e s$ financial reporting.

Keywords: Management, Accountability, Financial Statements, BUMDes.

\section{PENDAHULUAN}

Pada sisi perekonomian, BUMDes merupakan pilar kegiatan ekonomi di desa yang berfungsi sebagai lembaga sosial (social institution) yang berpihak kepada kepentingan masyarakat melalui kontribusinya dalam penyediaan pelayanan sosial. Tidak hanya itu saja, BUMDes juga berfungsi sebagai lembaga komersial (commercial institution) yang bertujuan mencari keuntungan melalui penawaran sumber daya lokal (barang dan jasa) ke pasar. BUMDes sebagai badan hukum, dibentuk berdasarkan tata perundang-undangan yang berlaku dan sesuai dengan kesepakatan yang terbangun di masyarakat desa. Dengan demikian, bentuk BUMDes dapat beragam di setiap desa di Indonesia sesuai dengan karakteristik lokal, potensi, dan sumber daya yang dimiliki masing-masing desa (Anonymus, 2007:3).

BUMDes juga diperkuat dengan adanya peraturan perundang-undangan maupun Peraturan Pemerintah (PP) yang mengamanatkan BUMDes, seperti yang tercantum di dalam Undang-Undang Republik Indonesia No. 32 Tahun 2004 tentang Pemerintahan Daerah dan Undang-Undang Republik Indonesia No. 6 Tahun 2014 tentang Desa. Tidak hanya itu saja, BUMDes juga diatur dalam Peraturan Pemerintah (PP) Republik Indonesia No. 72 Tahun 2005 tentang Desa, Peraturan Pemerintah (PP) Republik Indonesia No. 43 Tahun 2014 tentang Peraturan Pelaksanaan Undang-Undang No. 6 Tahun 2014 tentang Desa, kemudian yang terakhir yaitu diatur dalam Peraturan Menteri Desa Pembangunan Daerah Tertinggal dan Transmigrasi (PDTT) Republik Indonesia No. 4 Tahun 2015 tentang Pendirian, Pengurusan dan Pengelolaan, dan Pembubaran Badan Usaha Milik Desa.

Dilansir pada www.liputan6.com, Sekretaris Jenderal Kementerian Desa, Pembangunan Daerah Tertinggal (Sekjen Kemendes PDTT), Anwar Sanusi saat diwawancarai mengatakan ada sebanyak 45.549 BUMDes di Indonesia yang terbentuk dan kehadiran BUMDes ini diharapkan dapat membantu kegiatan perekonomian di desa. Kehadiran 45.549 unit BUMDes yang ada di Indonesia hingga Desember 2018 apabila di persentasekan maka sebanyak 61\%. Jumlah BUMDes yang ada pada akhir tahun 2018 ini meningkat tinggi dibandingkan dari tahun 2014 yang hanya terdapat sekitar 1.022 unit BUMDes saja.

Berkembangnya jumlah BUMDes di Indonesia diikuti juga dengan Pemerintah Provinsi Nusa Tenggara Barat yang menguatkan BUMDes di NTB dengan mendukung kerja sama antara Perusahaan Umum (Perum) Bulog Divre dengan PT. Gerbang NTB Emas (Persero). Program yang direncanakan untuk mengembangkan BUMDes dibantu dengan bantuan teknologi guna pembuatan jaringan bisnis Mahadesa TDC (Trade and Distribution Centre). Kerja sama ini dilakukan untuk mempersiapkan BUMDes di NTB menjadi pusat perdagangan dan distribusi logistik mengingat Bulog mengeluarkan produk bahan pokok seperti beras, gula, minyak dan telur yang nantinya akan disiapkan 


\section{Risinace}

Vol. 1 No. 4 Desember 2021

dengan harga lebih murah dan bisa dilayani oleh BUMDes baik secara online maupun offline.

Salah satu daerah yang berada di NTB yang pada daerahnya terdapat BUMDes yaitu Kecamatan Gunungsari yang berada di daerah Lombok Barat. Pemilihan BUMDes yang berada di Kecamatan Gunungsari ini karena ada beberapa BUMDes yang memiliki unit usaha yang menarik, selain itu Kecamatan Gunungsari merupakan salah satu daerah yang terkena dampak dari bencana alam gempa bumi pada tahun 2018 silam. Terdapat BUMDes di Kecamatan Gunungsari yang saat ini tidak beroperasi, yaitu BUMDes Desa Gunungsari dan BUMDes Desa Taman Sari yang merasakan dampak dari gempa 2018 sehingga kegiatan BUMDes menjadi terhenti. Di samping itu kondisi bangunan BUMDes Desa Taman Sari kini sudah luluh lantah akibat dari gempa bumi yang terjadi. Selain dari dampak yang ditimbulkan akibat gempa bumi, dari segi kondisi masyarakat Desa Taman Sari juga kurang mendukung keberadaan BUMDes, ini sama halnya dengan yang dialami oleh BUMDes di Desa Jeringo. Sebelumnya BUMDes di Desa Taman Sari dan Desa Jeringo bergerak dalam bidang usaha simpan pinjam, namun karena masyarakat sekitar tidak disiplin mengenai pengembalian uang pinjaman yang sudah diberikan, berakibat pada kemunduran perkembangan BUMDes. Adapun BUMDes di Desa Mekarsari yang saat ini tidak aktif, tetapi informasi lebih lanjut alasan dibalik mengapa BUMDes di Desa Mekarsari tidak aktif, tidak diungkapkan oleh Sekretaris Desa setempat. Tidak sampai disitu saja, BUMDes di Desa Ranjok juga mengalami pengelolaan BUMDes yang belum dilakukan secara maksimal, ini dikarenakan pengurus BUMDes yang masih memiliki kesibukan lain.

Pada pengelolaan penelitian ini mengacu pada penelitian yang dilakukan oleh Subaidi, dkk (2019). Di dalam penelitian tersebut, untuk mengetahui pengelolaan BUMDes dilihat dari fungsi-fungsi manajemen seperti perkiraan (forecasting), perencanaan (planning), pengorganisasian (organizing), pengendalian (actuating), dan pengendalian (controlling). Hasil dari penelitian Subaidi, dkk (2019) menunjukkan bahwa kurangnya sosialisasi oleh Kepala Desa dan Pengawas BUMDes ke masyarakat mengakibatkan masyarakat banyak yang belum mengerti tentang manfaat dan keuntungan BUMDes, selain itu adanya kekurangan berupa sarana dan prasarana dalam pengelolaan, kurangnya modal, kurangnya manajemen BUMDes dan kurangnya partisipasi masyarakat dalam pengelolaan BUMDes sehingga belum dapat dirasakan sesuatu yang positif dengan kehadiran BUMDes. Tidak hanya itu saja, untuk akuntabilitas penelitian ini merujuk pada penelitian yang dilakukan oleh Imawan, dkk (2019) melihat peran akuntabilitas pemerintah desa dalam membangun kepercayaan publik yang dimana dilihat dari sisi akuntabilitas vertikal dan akuntabilitas horizontal. Hasilnya adalah pemerintah desa telah berkomitmen untuk menerapkan akuntabilitas keuangan baik secara vertikal maupun horizontal yang sesuai dengan Permendagri Nomor 113 Tahun 2014. Akuntabilitas vertikal telah dilaporkan kepada Pemerintah Kabupaten/Kota dalam bentuk surat pertanggungjawaban (SPJ) secara berkala. Sementara itu, akuntabilitas horizontal telah dilaporkan dalam forum musyawarah desa setiap akhir tahun secara lisan ataupun secara administrasi.

Adapun kebaharuan penelitian sekarang dengan penelitian sebelumnya adalah (1) perbedaan lokasi penelitian, (2) pada penelitian sebelumnya dari Subaidi, dkk (2019) hanya membahas mengenai pengelolaan BUMDes saja, dan pada penelitian Imawan, dkk (2019) hanya membahas mengenai akuntabilitas saja, sedangkan penelitian saat ini membahas mengenai kedua-duanya yaitu pengelolaan dan akuntabilitas laporan keuangan BUMDes. 


\section{TINJAUAN LITERATUR}

\section{Teori Stewardship (Stewardship Theory)}

Teori stewardship menggambarkan situasi dimana para manajer tidaklah termotivasi oleh tujuan-tujuan individu tetapi lebih ditujukan pada sasaran hasil utama mereka untuk kepentingan organisasi, hal ini sama seperti yang diungkapkan juga oleh Donaldson dan Davis dalam Putri, dkk (2019).

\section{Badan Usaha Milik Desa (BUMDes)}

Badan Usaha Milik Desa (BUMDes) adalah lembaga usaha desa yang dikelola oleh masyarakat dan pemerintahan desa dalam upaya memperkuat perekonomian desa dan dibentuk berdasarkan kebutuhan dan potensi desa (Anonymus, 2007:4). Keberadaan BUMDes menjadi salah satu pertimbangan untuk menyalurkan inisiatif masyarakat desa, mengembangkan, mengelola dan memanfaatkan potensi sumber daya alam desa, mengoptimalkan sumber daya manusia (SDM) dalam pengelolaannya, dan adanya penyertaan modal dari Pemerintah Desa dalam bentuk pembiayaan dan kekayaan desa yang diserahkan untuk dikelola sebagai bagian dari BUMDes (Kiha, dkk 2019).

\section{Pengelolaan}

Follet dalam Nurliani, dkk (2018) mendefinisikan pengelolaan adalah seni atau proses dalam menyelesaikan sesuatu yang terkait dengan pencapaian tujuan. Dalam penyelesaian sesuatu tersebut, terdapat tiga faktor yang mendasari antara lain: (1) adanya penggunaan sumber daya organisasi, baik sumber daya manusia maupun faktor-faktor produksi lainya, (2) proses yang bertahap mulai dari perencanaan, pengorganisasian, pengarahan dan pengimplementasian, hingga pengendalian dan pengawasan, dan (3) adanya seni dalam penyelesaian pekerjaan. Nurliani, dkk (2018) juga mengatakan bahwa pengelolaan merupakan terjemahan dari kata "management", istilah inggris tersebut lalu di Indonesia menjadi manajemen. Manajemen berasal dari kata to manage yang artinya mengatur, pengaturan dilakukan melalui proses dan diatur berdasarkan urutan dari fungsifungsi manajemen.

\section{Akuntabilitas}

Dalam Kholmi (2016), Gray, et al. memberikan pengertian bahwa akuntabilitas adalah tentang pemberian informasi antara dua pihak, dimana yang satu adalah yang bertanggungjawab memberikan penjelasan atau justifikasi terhadap pihak yang lain yang memiliki hak atas pertanggungjawaban tersebut. Mardiasmo dalam Kholmi, (2016) mendefinisikan akuntabilitas publik adalah kewajiban pihak pemegang amanah (agent) untuk memberikan pertanggungjawaban, menyajikan, melaporkan, dan mengungkapkan segala aktivitas dan kegiatan yang menjadi tanggungjawabnya kepada pihak pemberi amanah (principal) yang memiliki hak dan kewenangan untuk meminta pertanggungjawaban tersebut.

\section{Laporan Keuangan}

Adanya tuntutan yang semakin besar terhadap pelaksanaan akuntabilitas publik menimbulkan implikasi bagi manajemen sektor publik untuk memberikan informasi kepada publik, salah satunya adalah informasi akuntansi yang berupa laporan keuangan. Nordiawan dalam Irawati, dkk (2017) menjelaskan bahwa laporan keuangan merupakan bentuk pertanggungjawaban atas pengelolaan sumber daya ekonomi yang dimiliki oleh suatu entitas. Laporan keuangan harus disusun sesuai dengan standar akuntansi yang berlaku agar laporan keuangan tersebut dapat dibandingkan dengan laporan keuangan sebelumnya.

Pengertian sederhana menurut Kasmir dalam Jayanti, dkk (2018) laporan keuangan adalah laporan yang menunjukkan kondisi keuangan perusahaan pada saat ini 


\section{Risinear}

Vol. 1 No. 4 Desember 2021

atau dalam suatu periode tertentu. Maksud laporan keuangan yang menunjukkan kondisi keuangan perusahaan saat ini adalah merupakan kondisi terkini. Kondisi perusahaan terkini adalah keadaan keuangan perusahaan pada tanggal tertentu (untuk neraca) dan periode tertentu (untuk laporan laba rugi). Laporan keuangan menggambarkan pos-pos keuangan perusahaan yang diperoleh dalam suatu periode.

\section{Rerangka Konseptual}

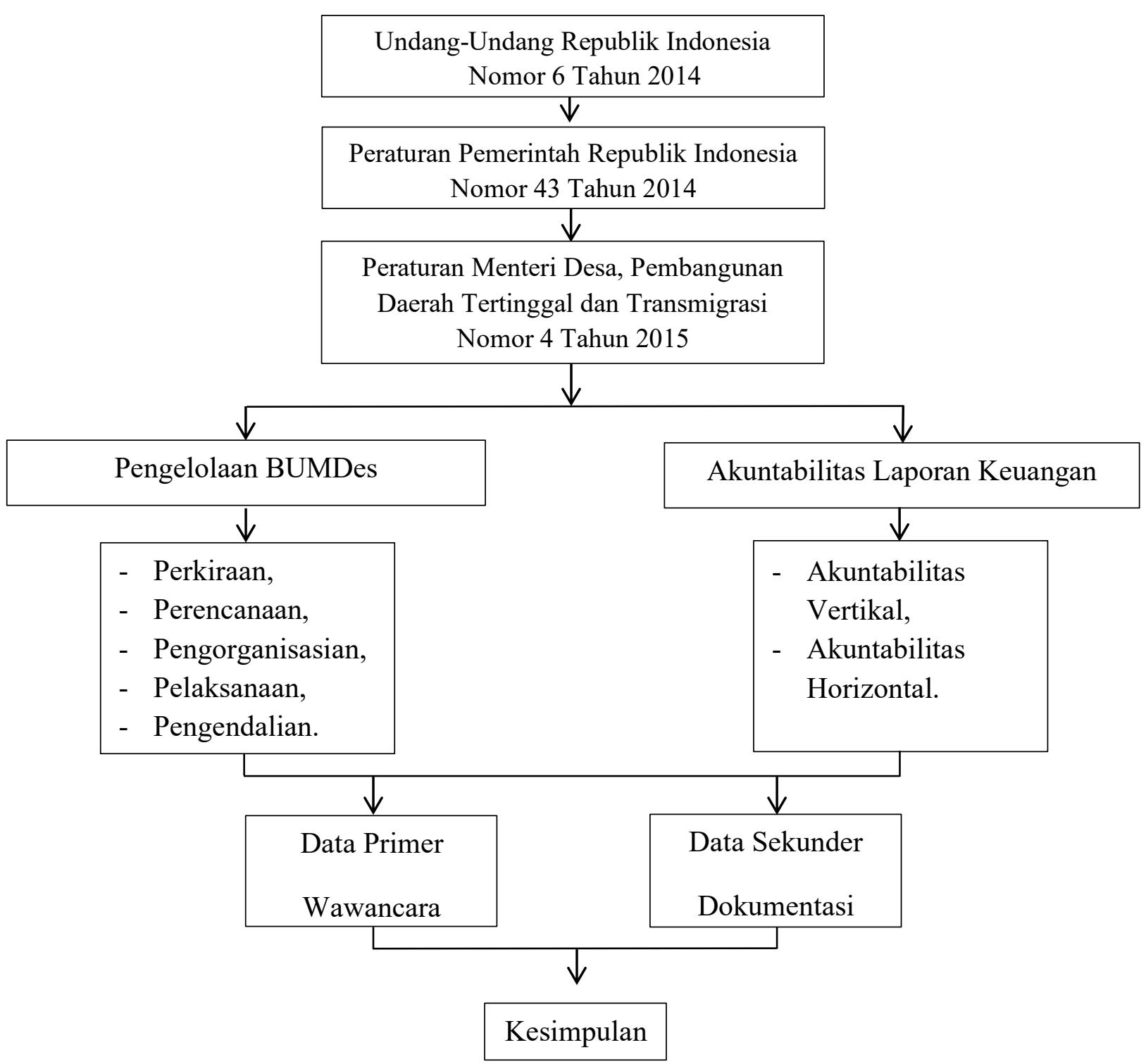

\section{METODE PENELITIAN}

Jenis penelitian yang digunakan dari penelitian ini adalah penelitian deskriptif dengan pendekatan kualitatif.

Informan pada penelitian ini diambil dari situasi BUMDes di Kecamatan Gunungsari Kabupaten Lombok Barat, dimana narasumber merupakan Perangkat Desa (Kepala Desa/Sekretaris Desa), Ketua BUMDes serta Ketua BPD. Peneliti merupakan instrumen kunci utama dalam mengungkapkan makna dan sekaligus sebagai alat pengumpul data. Oleh karena itu dalam penelitian ini peneliti terjun langsung ke lapangan 
untuk mengamati dan mengumpulkan data yang dibutuhkan tanpa diwakilkan oleh pihak lain.

Sementara instrumen penelitian ini adalah wawancara yang ditujukan langsung kepada Perangkat Desa (Kepala Desa/Sekretaris Desa), Ketua BUMDes serta Ketua BPD. Instrumen tersebut disusun berdasarkan indikator yang terkandung dalam pengelolaan dan akuntabilitas yang kemudian dijabarkan dalam item-item pertanyaan.

\section{Analisis Data}

a. Reduksi data (data reduction), berarti merangkum, memilih hal-hal yang pokok, memfokuskan pada hal-hal penting, dicari tema dan polanya. Dengan demikian, data yang telah di reduksi akan memberikan gambaran yang lebih jelas, dan mempermudah peneliti untuk melakukan pengumpulan data selanjutnya, dan mencarinya bila diperlukan (Sugiyono, 2016:247).

b. Penyajian data (data display), dalam hal ini Miles dan Huberman (1984) menyatakan yang paling sering digunakan untuk menyajikan data dalam penelitian kualitatif adalah dengan teks yang bersifat naratif. Dengan mendisplaykan data, maka akan memudahkan untuk memahami apa yang terjadi, dan merencanakan kerja selanjutnya berdasarkan apa yang telah dipahami tersebut (Sugiyono, 2016:249).

c. Penarikan kesimpulan (conclusion drawing/verification), kesimpulan awal yang dikemukakan masih bersifat sementara, dan akan berubah bila tidak ditemukan buktibukti yang kuat yang mendukung pada tahap pengumpulan data berikutnya. Tetapi apabila kesimpulan yang dikemukakan pada tahap awal, didukung oleh bukti-bukti yang valid, dan konsisten saat peneliti kembali ke lapangan mengumpulkan data, maka kesimpulan yang dikemukakan merupakan kesimpulan yang kredibel. Dengan demikian kesimpulan dalam penelitian kualitatif mungkin dapat menjawab rumusan masalah yang dirumuskan sejak awal, tetapi mungkin juga tidak, karena seperti telah dikemukakan bahwa masalah dan rumusan masalah dalam penelitian kualitatif masih bersifat sementara dan akan berkembang setelah penelitian berada di lapangan (Sugiyono, 2016:253).

\section{HASIL DAN PEMBAHASAN}

Pengelolaan pada penelitian ini dilihat dari indikator perkiraan, perencanaan, pengorganisasian, pelaksanaan, pengendalian.

Perkiraan (forecasting), BUMDes yang menjadi sampel pada penelitian ini melakukan perkiraan terkait dengan keberlanjutan usahanya dengan Ketua BUMDes yang memiliki caranya sendirisendiri, yaitu seperti dengan melihat apa yang sedang dibutuhkan oleh masyarakat, sehingga nantinya bisa mengikuti keinginan atau kebutuhan pasar, melakukan terobosan-terobosan dengan kata lain terus berinovasi agar usaha tetap berjalan dan terus berkembang. Kemudian melakukan pengusulan penambahan modal untuk memperbaharui unit usaha agar usaha tidak stuck hanya pada kegiatan unit usaha yang itu-itu saja. Menyerahkan kembali kepada kebijakan Pemerintah Desa setempat juga merupakan pilihan yang diambil oleh Ketua BUMDes karena BUMDes tidak bisa berjalan sendiri tanpa Kepala Desa sebagai penasihat BUMDes dan pihak BPD sebagai pengawas BUMDes. Selain itu dilakukan juga melihat potensi serta peluang usaha yang ada disekitar, jadi tidak hanya terpaku pada satu usaha namun dapat mengembangkan lagi unit usaha.

Perencanaan (planning), dalam penentuan unit usaha dilakukan melalui proses musyawarah seperti yang dilakukan oleh BUMDes Karya Bersama di Desa Dopang dan BUMDes Selun Jari di Desa Midang, sehingga terpilihlah usaha yang dijalani saat ini. 


\section{Risinace}

Vol. 1 No. 4 Desember 2021

Disamping itu BUMDes Selun Jari di Desa Midang juga menentukan unit usaha yang hendak dijalani dengan melihat dari segi tempat yang strategis, peluang usaha memumpuni dan kebutuhan masyarakat, juga dilakukan oleh BUMDes Sari Kencana di Desa Gelangsar, BUMDes Remaja di Desa Jatisela, BUMDes Remasa di Desa Kekait dan BUMDes Maju Bersama di Desa Sesela. Untuk program kerja yang dijalankan oleh BUMDes yang berada di Kecamatan Gunungsari tentunya bermacammacam, semua dikondisikan kembali dengan hasil keputusan pada musyawarah penentuan unit usaha yang akan dijalani dan disesuaikan juga dengan peluang yang ada.

Dalam tahap perencanaan tentunya visi dan misi juga ditetapkan untuk memastikan dan memperkuat landasan BUMDes yang hendak dicapai setelah resmi terbentuknya BUMDes. Penentuan visi dan misi dilakukan agar BUMDes memiliki tujuan yang jelas dan terarah sehingga konsisten dalam pengelolaannya. Dari enam BUMDes yang menjadi sampel pada penelitian ini, rata-rata sudah memiliki visi dan misi yang sudah ditetapkan hanya saja belum tercetak dan terpampang. Adapun BUMDes yang belum menetapkan visi dan misinya yaitu BUMDes Remaja yang berada di Desa Jatisela, hal ini dikarenakan visi dan misi BUMDes sedang dalam tahap perancangan.

Prosedur kerja ini dibuat untuk memudahkan pengurus BUMDes menjalankan program kerja yang telah ditetapkan. BUMDes yang berada di Kecamatan Gunungsari sudah memiliki prosedur kerja yang jelas, misalnya seperti pedoman kegiatan BUMDes, jam operasional BUMDes yang dijalankan, dan kriteria dari pengurus BUMDes. Namun tidak semua BUMDes di Kecamatan Gunungsari memiliki prosedur kerja dan dijalankan dengan maksimal, seperti contohnya BUMDes Karya Bersama yang berada di Desa Dopang, dimana prosedur kerja sudah ada tetapi pelaksanaannya belum dilakukan secara maksimal sehingga BUMDes hanya beroperasi semampunya saja.

Untuk menunjang program kerja dan kegiatan operasional dari BUMDes tentunya harus tersedianya fasilitas sarana/prasarana yang digunakan untuk memaksimalkan pekerjaan pengurus BUMDes. Berdasarkan dari hasil wawancara dengan tiap Ketua BUMDes, Kepala Desa dan Ketua BPD yang menjadi sampel pada penelitian ini, didapatkan hasil bahwa fasilitas seperti bangunan gedung untuk BUMDes memang sudah disediakan terlebih dahulu, kemudian untuk keperluan lain-lain daru BUMDes selanjutnya dirampungkan setelah kepengurusan BUMDes resmi terbentuk agar dapat disesuaikan dengan kebutuhan yang diperlukan untuk menunjang keberadaan BUMDes di desa masing-masing.

Pengorganisasian (organizing), proses pemilihan atau penentuan pengurus BUMDes di Kecamatan Gunungsari pada sampel penelitian ini dilakukan melalui proses musyawarah dengan mengundang tokohtokoh penting pada desa setempat dan perwakilan masyarakat. Jadi proses pemilihan Ketua, Sekretaris dan Bendahara untuk dijadikan pengurus inti dari BUMDes dilakukan secara terbuka tanpa adanya kepentingan pribadi yang mendasari penunjukan dari pengurus BUMDes yang berada di Kecamatan Gunungsari.

Setelah pengurus BUMDes terpilih, tentunya didapatkan seperti apa gambaran struktur organisasi BUMDes dengan orangorang yang sudah terpillih melalui proses musyawarah. Melalui struktur organisasi tentunya melengkapi perlengkapan BUMDes dan memudahkan untuk mengetahui siapa saja orang yang terlibat dalam pengelolaan BUMDes. BUMDes yang memiliki struktur organisasi namun tidak dipampang yaitu BUMDes Karya Bersama di Desa Dopang, BUMDes Sari Kencana di Desa Gelangsar, BUMDes Selun Jari di Desa Midang dan BUMDes Maju Bersama di Desa Sesela. Sedangkan untuk BUMDes lain seperti BUMDes Remaja di Desa Jatisela dan BUMDes Remasa di Desa Kekait belum memiliki struktur organisasi. Adapun alasan mengapa 
BUMDes Remaja di Desa Jatisela belum memiliki struktur organisasi karena pengelola unit-unit usaha BUMDes belum lengkap, berbeda halnya dengan BUMDes Remasa di Desa Kekait yang dimana karena mengalami perombakan pada pengurus sehingga struktur organisasi belum diperbaharui kembali.

Untuk memudahkan dalam menjalankan operasional BUMDes tentunya masingmasing pengurus mempunyai job desc masing-masing. Dengan adanya job desc ini pekerjaan masing-masing pengurus lebih terorganisir dengan rapi sehingga pengurus fokus pada pekerjaannya. Ketua BUMDes yang bertugas sebagai pemimpin BUMDes tentunya menguasai dan bertanggungjawab mengenai apa saja yang harus dilakukan oleh pengurus lain, sehingga pemberian tugas harus disampaikan kepada pengurus lain dengan mendetail agar tidak terjadi miskomunikasi. Lima dari enam Ketua BUMDes sudah mengetahui apa saja job desc dari masing-masing pengurus. Sementara BUMDes yang belum mengetahui secara mendetail job desc dari pengurus BUMDes Ketua BUMDes Remaja di Desa Jatisela. Berdasarkan penuturannya, beliau, mengatakan baru berbaur (karena baru menjadi Ketua BUMDes akhir 2019) sehingga masih sedikit pengetahuan yang ia ketahui mengenai BUMDes, oleh sebab ia mengatakan sambil (BUMDes) jalan, sambil belajar memperdalam dan memahami BUMDes.

Dalam hal memaksimalkan kinerja pengurus BUMDes, tentunya tidak luput dari diperlukannya pemberian motivasi kepada pengurus BUMDes. Melalui pemberian motivasi diharapkan pengurus BUMDes menjadi lebih bersemangat bekerja dan maksimal dalam bekerja guna mencapai visi dan misi yang telah ditetapkan. Pemberian motivasi ini tentunya juga dilakukan di BUMDes Kecamatan Gunungsari. Pemberian motivasi dilakukan baik dari Ketua BUMDes kepada pengurus lain, dari Kepala Desa kepada BUMDes, bahkan dari BPD kepada BUMDes. Pemberian motivasi yang diberikan untuk memaksimalkan kinerja tidak hanya melalui pemberian kalimatkalimat dorongan saja, melainkan juga melalui study banding ke desa lain, pemberian pelatihan, dan mensupport dalam bentuk pemberian dana. Sementara untuk Ketua BUMDes Remasa di Desa Kekait belum menerapkan sistem pemberian motivasi kepada pengurus lain di BUMDes Remasa, namun yang dilakukan adalah melakukan kunjungan dan diskusi ringan apabila terjadi kendala yang kemudian akan diteruskan kepada Kepala Desa dan BPD setempat sesuai dengan kebijakan selanjutnya.

Tidak hanya sebatas pemberian motivasi saja dilakukan untuk memaksimalkan BUMDes, tentu diperlukan adanya pemberian kritik dan saran yang membangun untuk memperbaiki BUMDes ke arah yang lebih baik. Selain masyarakat berbelanja pada BUMDes, pemberian kritik dan saran ini termasuk sebagai keterlibatan masyarakat dalam membangun BUMDes di desanya. Mengapa demikian? karena sasaran pasar dari BUMDes adalah masyarakat desa setempat sehingga BUMDes harus mengetahui bagaimana tanggapan dari masyarakat selaku sasaran pasar atau konsumennya. Masyarakat setempat diberikan ruang untuk menyalurkan aspirasi mereka dalam hal pemberian kritik dan saran kepada BUMDes baik melalui sosial media, musyawarah bahkan pihak pengurus BUMDes terjun langsung ke masyarakat. Jadi dari pihak BUMDes sangatlah terbuka apabila ada kritik dan masukan yang diberikan oleh masyarakat kepada pihak BUMDes.Pengelolaan BUMDes yang dilakuan dengan melibatkan masyarakat diharapkan mampu untuk mendorong perekonomian desa dengan meningkatkan kesejahteraan masyarakat.

Pelaksanaan (actuating), berkaitan dengan pelaksanaan ini tentunya dilihat dari seberapa jauh program kerja yang ditetapkan dapat berjalan sebagaimana yang sudah direncanakan. Seperti program kerja BUMDes Karya Bersama yang berada di Desa 


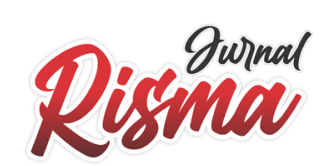

Vol. 1 No. 4 Desember 2021

Dopang yang dimana program kerja BUMDes memang sudah berjalan, tetapi belum dapat dikatakan maksimal karena BUMDes belum memberikan PADes sebagai bentuk sumbangsih untuk memajukan perekonomian desa. Sama halnya dengan BUMDes Sari Kencana di Desa Gelangsar, secara kondisi BUMDes sudah dapat dikatakan maksimal tetapi untuk mendapatkan keuntungan yang banyak memang belum, sehingga BUMDes di Desa Gelangsar ini tetap harus berproses. Sementara itu untuk BUMDes Remaja di Desa Jatisela dari segi pelaksanaan juga belum dapat dikatakan maksimal, terlebih lagi BUMDes Remaja pernah dibekukan dua kali dan ketika akan bangkit pada tahun 2020, terhalang oleh Pandemi Covid-19 yang mengakibatkan BUMDes tidak dapat beroperasi dengan maksimal. Untuk BUMDes Remasa di Desa Kekait pelaksanaannya belum maksimal karena kepengurusan BUMDes yang baru diperbaharui kembali sehingga masih dalam tahap evaluasi.

Dalam pelaksanaan BUMDes juga dibutuhkan dukungan, kritik dan saran dari berbagai lapisan seperti dari pihak Kabupaten, pihak pemerintah desa, masyarakat setempat dan desa-desa lain yang memiliki BUMDes dengan pelaksanaan yang baik untuk dijadikan contoh dalam pengelolaan BUMDes. Selanjutnya yaitu BUMDes Selun Jari yang berada di Desa Midang, yang pelaksanaannya sudah sesuai dengan ketetapan yang ada. Yang terakhir yaitu BUMDes Maju Bersama yang berada di Desa Sesela, secara pelaksanaan BUMDes memang sudah berjalan, tetapi walaupun demikian BUMDes tetap harus memperbaiki sistem pola pemasaran dan sistem jam kerja dari pengurus BUMDes yang lain sehingga nantinya akan pelaksanaan BUMDes dapat berjalan maksimal. Tentunya hal ini tidak terlepas juga dari bantuan pihak BPD yang memberikan masukan, kritikan serta arahan bagi BUMDes Maju Bersama.

Pengendalian (controlling), pengendalian yang dimaksudkan pada penelitian ini yaitu terkait evaluasi dari program kerja BUMDes yang bertujuan untuk mengetahui kinerja dari BUMDes. BUMDes Karya Bersama di Desa Dopang yang belum pernah dilakukan evaluasi, hal ini dikatakan oleh Sekretaris Desa dan Ketua BPD setempat. Sementara Ketua BUMDes Karya Bersana mengatakan bahwa evaluasi program kerja BUMDes dilakukan tidak menentu dengan melibatkan anggota BUMDes dan pendamping desa.

Kemudian untuk BUMDes Sari Kencana di Desa Gelangsar, berdasarkan penuturan dari Ketua BUMDes bahwa pelaksanaan evaluasi dari program kerja BUMDes dilakukan setahun dua kali dengan Pemdes, BPD dan stakeholder desa Gelangsar, tentunya dengan semua pengurus BUMDes. Sementara itu, Kepala Desa di Desa Gelangsar mengatakan bahwa evaluasi program kerja dilakukan dua belas bulan setelah pembentukan atau reshuffle. Berbeda lagi dengan Ketua BPD di Desa Gelangsar mengatakan bahwa evaluasi program kerja dilakukan dua bulan sekali dan pada akhir tahun mendengarkan pertanggungjawaban saja.

Saat diwawancarai mengenai kapan pelaksanaan evaluasi terkait program kerja BUMDes Remaja di Desa Jatisela, Ketua BUMDes mengatakan bahwa waktu pelaksanaan evaluasi tidak terjadwal, sehingga sekiranya ada di evaluasi pada hari itu, maka akan di evaluasi. Berbeda dengan penuturan dari Kepala Desa di Desa Jatisela, beliau mengatakan bahwa evaluasi program kerja BUMDes dilakukan tiga bulan sekali. Jawaban yang berbeda diungkapkan oleh Ketua BPD di Desa Jatisela, evaluasi program kerja BUMDes dilaksanakan berdasarkan Peraturan Desa, waktu pelaksanaan evaluasi dilakukan enam bulan sekali, namun memang untuk saat ini evaluasi BUMDes Remaja belum dilakukan karena Ketua BUMDes belum enam bulan menjabat, ungkap Ketua BPD di Desa Jatisela. 
Sementara itu jawaban yang selaras disampaikan oleh Ketua BUMDes Remasa Desa Kekait dan Sekretaris Desa di Desa Kekait. Dikatakan untuk acuan pelaksanaan dari evaluasi yaitu setiap triwulan, enam bulan dan satu tahun tetapi mengenai evaluasi di BUMDes Remasa saat ini belum dilakukan. Tidak hanya BUMDes Remasa di Desa Kekait saja, jawaban selaras juga didapatkan saat melakukan wawancara dengan BUMDes Selun Jari di Desa Midang, evaluasi program kerja dilakukan enam bulan sekali dan untuk keseluruhan dilakukan setahun sekali, dan tidak lupa juga setiap bulannya laporan keuangan tetap ada dari masing-masing unit usaha BUMDes, begitu juga dengan yang diungkapkan oleh Kepala Desa setempat yang mengatakan bahwa evaluasi dilakukan secara tahunan.

Untuk evaluasi program kerja yang dilakukan oleh BUMDes Maju Bersama, berdasarkan pengakauan dari Ketua BUMDes terkait evaluasi secara unit dilakukan dua minggu sekali oleh BUMDes, dan evaluasi laporan perkembangan secara keseluruhan dilakukan tiga bulan sekali. Sementara Kepala Desa mengatakan evaluasi yang dilaksanakan bersama forum baru dilaksanakan dua kali yaitu pada pemabahasan APBDes tanggal 24 Maret 2020. Sementara menurut jawaban dari pihak BPD, evaluasi kepada BUMDes dilakukan satu tahun sekali. Namun apabila ada urgent tidak menutup kemungkinan evaluasi dilakukan dengan pemanggilan khusus oleh BPD.

Sementara mengenai akuntabilitas, pada penelitian ini membahas mengenai akuntabilitas vertikal dan akuntabilitas horizontal.

Akuntabilitas Vertikal, pelaporan keuangan BUMDes yang disampaikan kepada pihak Pemerintah Desa (internal) belum sepenuhnya dilaksanakan oleh BUMDes-BUMDes yang berada di Kecamatan Gunungsari. Pelaporan tersebut belum dilakukan oleh BUMDes Karya Bersama di Desa Dopang, BUMDes Sari Kencana di Desa Gelangsar, dan BUMDes Remaja di Desa Jatisela. Rata-rata alasan dari BUMDes-BUMDes tersebut belum membuat laporan keuangan yaitu karena kepengurusan belum satu tahun berjalan atau baru terbentuk dan diperbaharui kembali. Sehingga dapat dikatakan bahwa dari segi akuntabilitas vertikal (internal) belum sepenuhnya dilakukan.

Sementara itu untuk BUMDes yang sudah membuat laporan keuangan keuangan yaitu BUMDes Remasa di Desa Kekait yang dimana laporan tersebut memuat transaksi harian untuk bulan Agustus 2020 dan September 2020 serta laporan laba/rugi bulan Agustus 2020. Selain itu BUMDes Selun Jari di Desa Midang telah membuat laporan keuangan yang dibuat per-enam bulan oleh BUMDes, tetapi laporan keuangan tersebut disampaikan kepada pihak Pemerintah Desa, BPD dan forum satu tahun sekali bersamaan dengan laporan evaluasi program kerja BUMDes. Untuk BUMDes Maju Bersama di Desa Sesela sedang dalam proses penyusunan laporan keuangan.

Akuntabilitas Horizontal, laporan keuangan yang akan diserahkan dari BUMDes kepada pihak BPD (eksternal) juga tidak jauh berbeda hasilnya dengan laporan keuangan yang akan diserahkan oleh BUMDes kepada pihak Pemerintah Desa (internal). BUMDes yang belum membuat laporan keuangan yaitu BUMDes Karya Bersama di Desa Dopang, BUMDes Sari Kencana di Desa Gelangsar, dan BUMDes Remaja di Desa Jatisela. Untuk BUMDes Remasa di Desa Kekait membuat catatan transaksi harian untuk bulan Agustus 2020 dan laporan laba/rugi bulan AGustus 2020. Sementara untuk BUMDes Selun Jari di Desa Midang, karena laporan keuangan BUMDes diteruskan kepada pihak Pemerintah Desa dan BPD secara bersamaan, sehingga untuk pemberian laporan keuangan tersebut dibuat per-enam bulan oleh BUMDes dan diserahkan kepada kedua belah pihak tersebut dengan waktu pelaporan satu tahun sekali bersamaan dengan laporan evaluasi program kerja BUMDes. Pada laporan tersebut memuat tentang laporan pembagian jasa, laporan 


\section{Risinace}

Vol. 1 No. 4 Desember 2021

laba/rugi, laporan perubahan laba/rugi, laporan perubahan modal, serta laporan harta tetap dan harta lancar. Sementara untuk BUMDes Maju Bersama di Desa Sesela terkait laporan keuangan sedang dalam tahap penyusunan laporan keuangan.

\section{KESIMPULAN DAN SARAN \\ Kesimpulan}

Berdasarkan pengelolaan dari Badan Usaha Milik Desa (BUMDes) yang ada di Kecamatan Gunungsari Kabupaten Lombok Barat, dilihat dari indikator perkiraan (perkiraan), perencanaan (planning), pengorganisasian (organizing), pelaksanaan (actuating), dan pengendalian (controlling). Sebagaimana hasil pada temuan data di lapangan, pengelolaan yang ada pada BUMDes di Kecamatan Gunungsari Kabupaten Lombok Barat belum sepenuhnya berjalan maksimal sesuai dengan harapan. Ini karena masih adanya problem yang didapatkan pada setiap BUMDes. Seperti pada tahap perencanaan, terdapat BUMDes yang memiliki prosedur kerja tetapi belum dijalankan maksimal yaitu BUMDes Karya Bersama di Desa Dopang dan BUMDes Remaja di Desa Jatisela yang belum memiliki visi dan misi. Pada tahap pengorganisasian belum dilaksanakan dengan baik oleh BUMDes Remaja di Desa Jatisela karena BUMDes tersebut belum memiliki struktur organisasi dan belum mengetahui secara mendetail job desc dari pengurus BUMDes. Begitu juga dengan BUMDes Remasa di Desa Kekait, belum memiliki struktur organisasi BUMDes dan belum melakukan pemberian motivasi kepada sesama pengurus. Terkait pelaksanaan, dari jawaban setiap informan di masingmasing desa, mengatakan bahwa pelaksanaan belum sepenuhnya dapat dikatakan maksimal, sehingga masih perlunya peningkatan dan proses untuk mengembangkan dan memajukan BUMDes. Kemudian yang terakhir pengendalian yang berkaitan dengan evaluasi dari program kerja BUMDes. Jawaban informan dari setiap desa beragam. Bahkan jawaban dari setiap informan di satu desa juga berbeda. Sehingga bisa dilihat bahwa belum adanya kekompakan didalam pemahaman dan menjalankan BUMDes pada sebuah desa.

Sementara itu mengetahui akuntabilitas dari laporan keuangan Badan Usaha Milik Desa (BUMDes) yang ada di Kecamatan Gunungsari Kabupaten Lombok Barat berkaitan dengan pelaporan keuangan dari segi akuntabilitas vertikal (internal) dan akuntabilitas vertikal (internal). BUMDes yang sudah membuat laporan keuangan dan memenuhi dokumen yang diperlukan untuk menunjang valid dari informasi yang diberikan adalah BUMDes Remasa di Desa Kekait dan BUMDes Selun Jari yang berada di Desa Midang. Sementara untuk BUMDes Maju Bersama di Desa Sesela sedang dalam proses penyusunan laporan keuangan yang dimana artinya laporan keuangan belum rampung. Untuk BUMDes lain seperti BUMDes Karya Bersama tidak membuat laporan keuangan karena kepengurusan saat ini belum memahami cara memuat laporan keuangan sehingga belum membuat dan menyerahkan laporan keuangan kepada pihak Pemerintah Desa dan BPD. Sementara untuk BUMDes Sari Kencana dan BUMDes Remaja saat dihubungi kembali terkait laporan keuangan susah untuk dihubungi karena tidak ada respon yang diberikan oleh Ketua BUMDes sehingga sulit untuk menggai informasi lebih lanjut.

\section{Saran}

Berdasarkan keterbatasan penelitian, maka diajukan beberapa saran, antara lain:

a. Peneliti selanjutnya diharapkan memilih BUMDes yang aktif dengan kepengurusan BUMDes yang sudah berjalan cukup lama sehingga dapat menggali sebanyak mungkin informasi yang dibutuhkan. 
b. Peneliti selanjutnya dapat meneliti BUMDes lain di Kecamatan lain yang berada di Kabupaten Lombok Barat untuk memberikan gambaran serta memperoleh informasi yang baru mengenai pengelolaan dan akuntabilitas laporan keuangan BUMDes lain di Kecamatan lain yang berada di Kabupaten Lombok Barat. Melengkapi dan menggali sebanyak-banyaknya dokumen penunjang yang dibutuhkan pada penelitian dengan menerapkan protokol kesehatan yang sudah dianjurkan.

\section{REFERENSI}

Anonim. 2007. Buku Panduan Pendirian dan Pengelolaan Badan Usaha Milik Desa (BUMDes). Departemen Pendidikan Nasional. Pusat Kajian Dinamika Sistem Pembangunan (PKDSP) Fakultas Ekonomi Universitas Brawijaya.

Asvi, Zul. 2017. Manajemen Badan Usaha Milik Desa (BUMDes) Bina Usaha Desa Kepenuhan Barat Kecamatan Kepenuhan Kabupaten Rokan Hulu. JOM FISIP. Vol. 4, No. 2. Hal: 1-15.

Bimtek Pengelolaan dan Pertanggungjawaban Keuangan BUMDes. https://www.bppkpd.id/pertanggungjawaban-keuangan-bumdes/, diakses pada tanggal 4 Januari tahun 2020.

BUMDes $\begin{array}{lllll} & \text { Sebagai } & \text { Pusat } & \text { Distribusi Pahan }\end{array}$ https://www.ntbprov.go.id/post/program-unggulan/bumdes-sebagaipusatdistribusi-bahan-pokok, diakses pada tanggal 4 Januari tahun 2020.

Fajri, Rahmi, Endah Setyowati dan Siswidiyanto. 2015. Akuntabilitas Pemerintah Desa Pada Pengelolaan Alokasi Dana Desa (ADD) Studi Pada Kantor Desa Ketindan, Kecamatan Lawang, Kabupaten Malang. Jurnal Administrasi Publik (JAP). Vol. 3, No. 7. Hal: 1099-1104.

Filya, Afifa Rachmanda. 2018. Optimalisasi Pengelolaan Badan Usaha Milik Desa (BUMDes) Dalam Meningkatkan PADES di Kecamatan Bojonegoro Kabupaten Bojonegoro Provinsi Jawa Timur. $J E \& K P$. Vol. 5, No. 1. Hal: 19-39.

Hardiningsih, Pancawati, Rachmawati Meita Oktaviani dan Ceacilia Srimindarti. 2019. Akuntabilitas Pengelolaan Alokasi Dana Desa Menuju Good Governance. Jurna STIE Semarang. Vol. 11, No. 3. Hal: 1-21.

Hastowiyono. dan Suharyanto. 2014. Seri Buku Pintar BUM Desa Penyusunan Kelayakan Usaha dan Perencanaan Usaha BUM Desa. Cetakan Pertama. Forum Pengembangan Pembaharuan Desa (FPPD). Yogyakarta.

Imawan, Amrizal, Gugus Irianto dan Yeney Widya Prihatiningtyas. 2019. Peran Akuntabilitas Pemerintah Desa Dalam Membangun Kepercayaan Publik. Jurnal Akuntansi Multiparadigma. Volume 10, Nomor 1. Hal: 156-175.

Irawati, Dina dan Diana Elvianita Martanti. 2017. Transparansi Pengelolaan Laporan Keuangan BUMDes Terhadap Pelaporan Aset Desa (Studi Fenomenologi Pada BUMDes Desa Karangbendo Kec Ponggok Kab Blitar). SNAPER-EBIS. Hal:4151.

Jayanti, Dwi, Masyhad dan Nurul Qomari. 2018. Analisis Penerapan SAK ETAP Pada Badan Usaha Milik Desa (BUMDesa) "Surya Sejahtera" Di Desa

Kedungturi Kecamatan Taman Kabupaten Sidoarjo. EQUITY. Vol. 4, Isssue. 3. Hal: 4762.

Jefri, Riny. 2018. Teori Stewardship dan Good Governance. Jurnal Riset Edisi XXVI. Vol. 4, No. 003. Hal: 14-28. 


\section{Risinace}

Vol. 1 No. 4 Desember 2021

Kholmi, Masiyah. 2016. Akuntabilitas Pengelolaan Alokasi Dana Desa: Studi di Desa Kedungbetik Kecamatan Kesamben Kabupaten Jombang. Ekonomika-Bisnis, Vol. 7, No. 2. Hal: 143-152.

Kiha, Emilia Khristina., dan Berno Benigno Mitang. 2019. Pemberdayaan Masyarakat Melalui Peningkatan Pengelolaan Badan Usaha Milik Desa (BUMDes) di Desa Tapenpah Kecamatan Insana Induk Kabupaten Timor Tengah Utara Provinsi Nusa Tenggara Timur. Jurnal Aksara Public. Vol. 3, No. 4. Hal: 248-259.

Lukito, Penny Kusumastuti. 2014. Membumikan Transparansi dan Akuntabilitas Kinerja Sektor Publik: Tantangan Berdemokrasi Ke Depan. PT Gramedia Widiasarana Indonesia. Jakarta.

Marala, Ryan, Hendro Wibowo dan Rachmat Rizky Kurniawan. 2018. Model Pengelolaan Badan Usaha Milik Desa (BUMDes) dalam Pembangunan Perekonomian Desa. (Studi Kasus Desa Masalima). Jurnal Ekonomi dan Perbankan Syariah. Vol. 6, No. 1.

Martani, Dwi, Sylvia Veronica Siregar, Ratna Wardhani, Aria Farahmita dan Edward Tanujaya. 2016. Akuntansi Keuangan Menengah Berbasis PSAK. Salemba Empat. Jakarta Selatan.

Moniaga, Steven Leonard. 2018. Perbandingan Gaya Kepemimpinan Agency dan Stewardship Theory Pada Generasi X dan Generasi Y Dalam Perusahaan Keluarga. PERFORMA: Jurnal Manajemen dan Start-Up Bisnis. Volume 2, Nomor 6. Hal:742-751.

Nosihana, Ariefia., dan Rizal Yaya. 2016. Internet Financial Reporting dan Faktor-Faktor yang Mempengaruhinya Pada Pemerintah Kota dan Kabupaten Di Indonesia. Jurnal Dinamika Akuntansi dan Bisnis. Vol. 3, No. 2. Hal:89-104.

Nurliani, Rina, Nur Fitriyah, Burhanudin. 2018. Peran Kepala BUMDes Dalam Pengelolaan Badan Usaha Milik Desa (BUMDes) di Desa Padang Jaya Kecamatan Kuaro Kabupaten Paser. eJournal Ilmu Pemerintahan. Vol. 6, No. 4.

Peraturan Pemerintah Republik Indonesia Nomor 72 Tahun 2005 Tentang Desa.

Peraturan Pemerintah Republik Indonesia Nomor 43 Tahun 2014 Tentang Peraturan Pelaksanaan Undang-Undang Nomor 6 Tahun 2014 Tentang Desa.

Peraturan Menteri Desa, Pembangunan Daerah Tertinggal Dan Transmigrasi Republik Indonesia Nomor 4 Tahun 2015 Tentang Pendirian, Pengurusan dan Pengelolaan, dan Pembubaran Badan Usaha Milik Desa.

Prasetyo, David. 2019. Peran BUMDES Dalam Membangun Desa. Cetakan Pertama. CV Derwati Press. Kalimantan Barat.

Putra, Anom Surya. 2015. Badan Usaha Milik Desa: Spirit Usaha Kolektif Desa. Cetakan Pertama. Kementerian Desa, Pembangunan Daerah Tertinggal, dan Transmigrasi Republik Indonesia. Jakarta Pusat.

Putri, Rinta Sefftyawati dan Sri Rahayu. 2019. Pengaruh Kinerja Keuangan Pemerintah Daerah Terhadap Belanja Modal di Provinsi Jawa Barat (Studi Empiris pada Kota/Kabupaten di Provinsi Jawa Barat Tahun 2014-2017). JASa (Jurnal Akuntansi, Audit dan Sistem Informasi Akuntansi). Vol. 3, No. 2. Hal: 256-268.

Rindi, Kadek, Luh Putu Mas Sintia Arsani Dewi, Dyah Ari Puspita Sari, dan Putu Pania Awitiana. 2017. Penerapan Prinsip Akuntabilitas Pada BUMDes Teja Kusuma. Jurnal Ilmiah Akuntansi dan Humanika. Vol. 7, No. 1.

Sarinah. 2017. Pengantar Manajemen. Deepublish (Grup Penerbitan CV Budi Utama). Yogyakarta. 
Subaidi, Moh, Slamet Muchsin, dan Khoiron. 2019. Manajemen Badan Usaha Milik Desa (BUMDes) Studi Di Dusun Somber Desa Robatal Kecamatan Robatal Kabupaten Sampang. Jurnal Respon Publik. Vol. 13, No. 5, Hal: 24-31.

Sugiyono. 2016. Metode Penelitian Kuantitaif, Kualitatif, dan R\&D. Bandung: Alfabeta. Sukasmanto. 2014. Seri Buku Pintar BUM Desa Rancang Bangun Bisnis dan Pengelolaan BUM Desa. Cetakan Pertama. Forum Pengembangan Pembaharuan Desa (FPPD). Yogyakarta.

Sukriani, Luh, Putu Eka Dianita Marvilianti Dewi, dan Made Arie Wahyuni. 2018. Pengaruh Tingkatan Pendidikan, Pengalaman Kerja, Pelatihan, dan Penggunaan Teknologi Informasi Terhadap Kualitas Laporan Keuangan BUMDes di Kecamatan Negara. JIMAT (Jurnal Ilmiah Mahasiswa Akuntansi) Universitas Pendidikan Ganesha. Vol. 9, No. 3. Hal: 85-97.

Sekjen Kemendes PDTT: BUMDes Diharapkan Jadi Penyangga Ekonomi Pedesaan:

https://www.liputan6.com/news/read/3950912/sekjen-kemendes-pdttbumdesdiharapkan-jadi-penyangga-ekonomi-pedesaan, diakses pada tanggal 21 September tahun 2019.

Undang-Undang Republik Indonesia Nomor 32 Tahun 2004 Tentang Pemerintahan Daerah.

Undang-Undang Republik Indonesia Nomor 6 Tahun 2014 Tentang Desa.

Utami, Yogi. 2018. Akuntabilitas Kinerja Perangkat Desa Dalam Pelaksanaan Program Desa Siaga di Desa Blang Benara Kabupaten Bener Meriah.

Skripsi. Program Studi Ilmu Administrasi Negara Konsentrasi Administrasi Pembangunan, Fakultas Ilmu Sosial dan Politik. Universitas Muhammadiyah Sumatera Utara.

Wahyudi, Agus. 2017. Akuntabilitas Pengelolaan Keuangan Desa di Kecamatan Unter Iwes Kabupaten Sumbawa. (Skripsi Sarjana yang tidak dipublikasikan, Univeristas Mataram).

Wardi, Khairul. 2019. Kajian Pengelolaan Badan Usaha Milik Desa (BUMDes) di Kabupaten Lombok Barat (Studi Empiris di Kecamatan Gunungsari, Batulayar dan Lingsar). (Skripsi Sarjana yang tidak dipublikasikan, Univeristas Mataram).

Wibowo, Angga Trie Sugiarto. 2016. Akuntabilitas Penyelenggaraan Asas Tugas Pembantuan di Desa Senduro Kecamatan Senduru Kabupaten Lumajang. Jurnal Penelitian Administrasi Publik. Vol. 2, No. 01. Hal: 185-201.

Wicaksono, Kristian Widya. 2015.Akuntabilitas Organisasi Sektor Publik. Jurnal Kebijakan \& Administrasi Publik (JKAP). Vol. 19, No. 1. Hal:3-15.

Widiastuti, Harjanti, Wahyu Manuhara Putra, Evy Rahman Utami, dan Rudy Suryanto. 2019. Mekanakar Tata Kelola Badan Usaha Milik Desa di Indonesia. Jurnal Ekonomi dan Bisnis. Vol. 22, No. 2. Hal: 257-288. 